\title{
The Impact of Organization Design on Work Performance of Cooperative Department, Small and Medium Enterprises Business of Trade in Bandung City
}

\author{
Imas Sumiati ${ }^{1}$, Yayan Mulyana ${ }^{2}$, Tine RatnaPoerwantika ${ }^{3}$ \\ 1,2,3 Faculty of Social and Political Sciences, Pasundan University

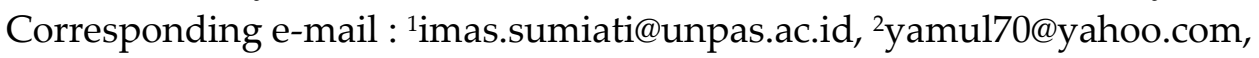 \\ 3tine.ratnapoerwantika@unpas.ac.id
}

\begin{abstract}
Based on the result of research in the Cooperative Office, Micro, Small and Medium Enterprises Bandung and the Department of Trade and Industry Bandung, there is work performance that has not been maximized, it can be seen from the indicators: the quantity of work, job knowledge and personal quality. This is due to: the complexity and formalization that have not been optimize. This research used combination research method by using Sequential Model that is with data and quantitative data analysis in first stage and with qualitative data in second stage. Technique collective data consist of literature study, field study (participant and non-participant observation, in-depth interviews with two heads of service, questionnaires distributed to 28 persons, Division Head and Section Head of both Focus Group Discussion), research design, data and data sources, key informant and informant, and documentation studies. The result of this research is quantitative result of $68.9 \%$ result of organizational design on work performance in Cooperation Department, Micro, Small and Medium Enterprises, Trade and Industry Office of Bandung City that have a high enough influence. The result of qualitative research is micro business that became a municipality affair then small enterprises are provincial affairs, and medium enterprises are the affairs of central government. This showed that there are still overlapping in work specialization and the authority that has not optimize yet from central to region, thus it needs a new concept or research findings that will certainly enrich organizational theory and study related to organizational structure and public institutional related to work performance.
\end{abstract}

Keyword: Organizational Structure, Work Performance, New SOTK.

Submited: 16 Desember 2017

\section{INTRODUCTION}

Organizations recognized the need to coordinate patterns of interaction of organization members formally. The organizational design defines how the task will be shared, who reports to whom, and the formal coordination mechanisms as well as patterns of interaction to follow.

WorkPerformance in the public sector, in essence is the work result achieved by the government apparatus, either individually, group or institution in accordance with the vision, mission and objectives that have been determined. In this context, there are many phenomena thatincreasingly interesting to observe. We see that, apparatus work performance that has not optimized yet in Office of Cooperatives, Small and Medium Enterprises and Industry Trade. 
Based on the results of studied research obtained work performance problems are as follows:

a. Quantity of work in this research the number of employees looks very less compared with diverse and the amount of guidance to be done to stakeholders called UMKMwith the amount of 5792 with the number of businesses more than 200 and nonformal business 27582 then the number of new entrepreneurs who pass the verification 1000, with the number of employees of NonFormal Business Sector 5 persons and SME Facility 7 people, also in trade of industrial centers of 30 not included superior (not recorded) must be managed by Industrial Planning and Development Division as many as 7 people.

b. Job knowledge the wider of knowledge regarding occupation and skill are also havenot optimize yet because if viewed from the knowledge of their employment in Cooperative Department, Micro, Small and Medium Business graduatedfrom Undergraduate degree of economics only 2 people, and for Master degree only management major and there is no economics field while in Department of Trade and Industry not recorded.

c. Personal quality or personal qualities of employees, once the author came to an institution, there was looked unconfident employeewho knewthere was a guest from the Ministry, although that employee has position as head of the field, he diverted for guest reception to other fields. The above problems allegedly caused by organization design that has not been optimized this case can be seen from :

a. Complexity, this is evident from the degree of labor division, the number of levels within the organizational hierarchy, and the extent to which geographically dispersed, organizational units are observed when the old SOTK where tasks, functions and principalities are almost simultaneous.

b. Formalization, this can be seen from the extent to which an organization relies on rules and procedures to regulate the behavior of its employees and all sorts of rules that instruct employees about what they can and cannot do. For example, when the old SOTK did not focus on the work, the overlapping in main task of function but when the new SOTK has been more focused, yet there are things that make the author interested in the organizational structure in the Office of Cooperatives, Micro, Small and Medium Enterprises while medium enterprises have been granted their authority to the province.

\section{A. Activity Objectives and Problem Solving Plan}

This study aims to, criticize old SOTK before the new SOTK; applying theory of organizational structure in theory that can be applied in organizational life related to cooperative service, small business also trade and industry; applied the results of this research to the offices that technically and operationally performed service activities, training to 
the public, other than that the department also coordinated with the other departments involved in its work performances; produced a work model of department duties that have many tasks and functions toproduce a working model structurereflected in the new organizational structure; replicating or repeating the design of old structures as the material of finding new structures: performs the prediction on work performance after new SOTK that enacted and it divided into 2 departments those are Cooperative Department, Micro, Small and Medium Enterprises of Bandung and Department of Trade and Industry in Bandung City; institutional arrangement of the two departments; product innovation of Micro, Small and Medium Enterprises; and network strengthening and cooperation.

This study used the theory of Organizational Design and work Performance in which the actual events in the two departments studied are expected to optimize the theories used as a framework of research thinking that became the guidance of this study so that the expected Organizational Design theory can be the basic theory of organizational structure developed in the working model in the two new SOTK services, it also expected to improve performance and focus more on implementing the organizational structure of the main tasks and functions of the two Department.

\section{B. Literature Review}

Griffin (2004: 352) defines that "organizational design is the whole set of structural elements and relationships among those elements that are used to manage the organization in total."
From the definition of the organization design is the unity of several parts that are arranged for each person occupy the office accompanied tasks, functions and obligations that must be implemented in order to facilitate the achievement of organizational goals.

According to Richard L. Daft (2010: 239), indicators of the organizational structure design are as follows: Work Specialization, organizations perform a very diverse task. The basic principle is that work can be done in a more efficient way if employees are allowed to do specification. Work specialization is sometimes called the division of labor, is the degree to which organizational tasks are divided into more specific individual work. Chain of Command, the chain of command is the line of authority that connects all the individuals within the organization and indicates to whom a reporter is concerned. It is related to two basic principles. Unity of command means that each employee is accountable only to one supervisor. The scalar principle refers to a clear definition of the line of authority within the organization that involves all employees. All personnel in the organization should know to whom they report and understand the full management level to the top. Authority is the formal right and legitimacy of a manager to make decisions, issue orders and allocate resources to achieve the desired outcomes of the organization.Management Range, range of management is the number of employees who report to a supervisor, sometimes also called as the span of control, the characteristics of this structure determine how close a supervisor can monitor a subordinate. Generally, when a supervisor has to get closer to his/her subordinates, the range will be smaller, and when supervisors need less involvement with 
subordinates, the range will be wider. Department, the department is the process of work merging into similar work groups. A similar group of work is named as a function. Each function is the task and responsibility of a particular unit within the organization. Work grouping or functionality is the foundation of organization management. Formalization, formalization is a written document that is used to direct and control the workers; the document includes regulatory books, policies, procedures, job descriptions and regulations. Those complemented documents fulfilled the organization chart and shows descriptions of tasks, responsibilities, decision-making of authority.

Understanding Work Performance by Ilyas (2005: 55), namely:

Performance is the appearance, the work result of the personnel, the quality, as well as the quantity of individual performance also the working group of personnel; the performance of the work is not limited to personnel who hold functional or structural positions but also to the whole range of personnel within the organization.

That definition explains that work performance is the result of work that can be shown in terms of quality and quantity, individually or in groups given by all parts of the organization.

There are several measurements of employee performance according to Faustino Cardoso Gomes in his book entitled Human Resource Management (2003: 142) are as follows: Quantity of work, the amount of work performed within a specified time period. Quality of work, quality of work achieved based on the requirements of suitability and readiness. Job knowledge, the breadth of knowledge about work and skills. Creativeness, the originality of ideas that arise from actions to resolve the problems that emerged. Cooperation, willingness to cooperate with others (fellow members of the organization). Dependability, awareness and credibility in terms of attendance and completion of work on time. Initiative, he spirit to carry out new tasks and in enlarging its responsibilities. Personal Quality, regarding personality and leadership, hospitality, as well as personal integrity.

\section{METHODS}

A. Objects and Places of Research

Department of Trade and Industry Bandung is one of the regional devices within the Government of Bandung that has the duty of performing functions of Business Affairs in the field of Trade and Industry. Establishment of Bandung Trade and Industry Department based on Local Regulation of Bandung Number 08 of 2016 regarding Establishment and Composition of Local Device of Bandung and Bandung Mayor Regulation Number 1395 of 2016 regarding Position, Organizational Structure, Duties and Function and Working Procedure of Department of Trade and Industry of Bandung City and Bandung Mayor Regulation Number 160 of 2017 regarding the Establishment, Position, Duties and Functions, Organizational Structure and Working Procedures of Technical Implementation Unit at the Department and Agency in Government of Environment in Bandung City.

Department of Cooperatives, Micro, Small and Medium Enterprises Bandung is an implementing element of Bandung City Government Affairs that organizes government affairs in the field of Cooperatives, micro, small and medium enterprises domiciled under and responsible to the Mayor through the Regional Secretary. Establishment of the Department of Trade and Industry 
Bandung is based on Local Regulations Bandung Number 08 of 2016 regarding the Establishment and Composition of Bandung Regional Devices and Bandung Mayor Regulation Number 1394 of 2016 regarding Position, Organizational Structure, Duties and Functions and Working Procedures Office of Cooperatives, Micro, Small and Medium Enterprises of Bandung City and Bandung Mayor Regulation Number 160 of 2017 regarding Formation, Position, Duties and Functions, Organizational Structure and Working Procedures Technical Implementation Unit at the Department and Agency in Government of EnvironmentBandung City.

The Office of Trade and Industry of Bandung and the Office of Cooperatives, Micro, Small and Medium Enterprises Bandung is located in one place (one building) at Jalan Kawaluyaan No. 2, Kota Bandung (022) 7308358.

B. Data Collection Technique

Data collection techniques consisted of literature study, field study (participant and non-participant observation, in-depth interviews to two Heads of Service, questionnaires distributed to 28 respondents that are Heads of Divisions and Section Heads of both Departments and Focus Group Discussion), research design, data and data sources, key informants are two Heads of Service and informants are some employees from two Departments, and documentation study.

C. Operational Definition of Research Variables

The table below item / item questioned is adjusted to the circumstances of the respondent regarding the questionnaire of the respondent's condition when the tryout of questionnaire objected because many of the questions were modified by the researcher who had been in accordance with Likert's theory. These are the following operational table of variables organizational design and work performance:
a. Operational Definition of Organizational Design Variables

\begin{tabular}{|c|c|c|c|c|c|}
\hline \multicolumn{2}{|l|}{ VARIABLE } & DIMENSION & INDICATOR & \multicolumn{2}{|c|}{ ITEM } \\
\hline \multirow{12}{*}{$\begin{array}{l}\text { Independent } \\
\text { Variable: } \\
\text { Organization } \\
\text { Design }(\mathrm{X})\end{array}$} & 1. & Work & a. Efficient work & 7 & - \\
\hline & & Specialization & b. Work divisions & - & 6 \\
\hline & 2 & & a. Unity of command & 1 & - \\
\hline & & Command & $\begin{array}{l}\text { b. Management level of } \\
\text { understanding }\end{array}$ & 11 & - \\
\hline & 3 & Authonity & a. Decision Making & 5 & - \\
\hline & & & b. Allocation of Resources & - & 12 \\
\hline & & & a. Instruction & - & 4 \\
\hline & 4. & Management Span & $\begin{array}{l}\text { b. Relation between superiors } \\
\text { and subordinates }\end{array}$ & - & 10 \\
\hline & & & $\begin{array}{l}\text { a. Merging of similar } \\
\text { employment }\end{array}$ & - & 8 \\
\hline & 5 . & Organizational & $\begin{array}{l}\text { b. Organization structure } \\
\text { arrangement representing } \\
\text { similar work grouping. }\end{array}$ & - & 2 \\
\hline & 6 & Fromolizetion & a. Control of work & 9 & - \\
\hline & 0. & Formalization & b. Documentation & 3 & - \\
\hline
\end{tabular}

Table 1. Operational Variable and Organization Design

b. Definition of Operational Variable of Work Performance

\begin{tabular}{|c|c|c|c|c|}
\hline VARIABLE & DIMENSION & INDICATOR & & \\
\hline \multirow{14}{*}{$\begin{array}{l}\text { Dependent } \\
\text { Variable : } \\
\text { Work } \\
\text { Performance (Y) }\end{array}$} & $\begin{array}{l}\text { 1. Quantity of } \\
\text { Work }\end{array}$ & $\begin{array}{l}\text { a. Finishing certain amount of } \\
\text { jobs as plamned }\end{array}$ & 27 & - \\
\hline & \multirow{2}{*}{$\begin{array}{l}\text { 2. Quality Of } \\
\text { Work }\end{array}$} & $\begin{array}{l}\text { b. Finishing current jobs on time } \\
\text { a. Abulity of employee's problem }\end{array}$ & . & 24 \\
\hline & & b. Doing jobs as procedure & 17 & . \\
\hline & \multirow{2}{*}{$\begin{array}{l}\text { 3. Job } \\
\text { Knowledge }\end{array}$} & a. Work knowledge & 13 & - \\
\hline & & b. Skills & - & 20 \\
\hline & \multirow[t]{2}{*}{ 4. Creativeness } & a. Creative ideas & 25 & - \\
\hline & & b. Creative solutions & . & 28 \\
\hline & \multirow[t]{3}{*}{ 4. Cooperation } & $\begin{array}{l}\text { a. Willingness to cooperate } \\
\text { b. Willingness to accept work }\end{array}$ & 15 & . \\
\hline & & partner's opimion & - & 18 \\
\hline & & a. Awareness & 21 & - \\
\hline & \multirow[t]{2}{*}{ 5. Dependability } & $\begin{array}{l}\text { b. Ability to explain current job } \\
\text { details }\end{array}$ & - & 14 \\
\hline & & a. Passion to do something new & 19 & - \\
\hline & 6. Initiative & $\begin{array}{l}\text { b. Agency's initiative on current } \\
\text { job }\end{array}$ & - & 26 \\
\hline & $\begin{array}{l}\text { 7. Personal } \\
\text { Qualities }\end{array}$ & a. Employee's Integrity & 23 & - \\
\hline
\end{tabular}

Table 2. Operational Variable of Employee's Work Performance

\section{Analysis Technique}

The research method used is combination research method using Sequential Model; Sequential Model combination method is a research procedure where the researcher develops research result from one method with other method. This method is said to be Sequential because of the use of consecutive combination methods, 
characterized by data collection and quantitative data analysis in the first stage and followed by the collection and analysis of qualitative data in the second stage. The following sequential explanatory design steps are as follows:

a. Quantitative Data Analysis Process

1. Validity Test

Testing the validity of the measuring instrument is first searched for equal correlation price between the parts of the measuring instrument as a whole by correlating each item with the total score thatis the sum of each score of item. Calculating the validity of the measuring tool using Rank Spearman correlation is the coefficient that takes into account the closeness of the relationship between two variables $X$ and $Y$ both have a scale measurement at least ordinal.

2. Reality Test

Reliable means trustful and can be fully relied on. The reliable result of the research is the result that has the similarities of data in different time. A good reliability showed a certain level of reliability, because this research uses the scaling system by using the Alpha Cronbach formula.

3. Regression Test

To test the influence of the researcher using simple linear regression formula, Imas Sumiati (2006: 2013) as follows:

If the $X$ variable was known first then $Y$ was determined base on this $X$, we can determine the relation $Y=F(X)$. The formula of this relation is known more as the regression of $\mathrm{Y}$ over $\mathrm{X}$.

If the regression of $Y$ over $X$ is liniear, the equation can be written in linear form $\hat{Y}=a+b x$.

b. Qualitative Analysis Data Process

The process of data analysis in qualitative research conducted before entering the field, during in the field, and after finished in the field. In qualitative research, data analysis is more focused during the process in the field along with data collection.

1) Analysis Before the Field

The analyses done towards preliminary study data, or secondary data, related to the focus on services in the Cooperative, Micro, Small and Medium Enterprises and Trade and Industry Service.

2) Analysis during the Field

This study used an "interactive analysis" model from Miles and Huberman. The Miles and Huberman model proposes four important components in collecting and analyzing data where they are interconnected and simultaneous; there were data collection, data reduction, data display, and conclusions, as visualized in the following figure ${ }^{1}$

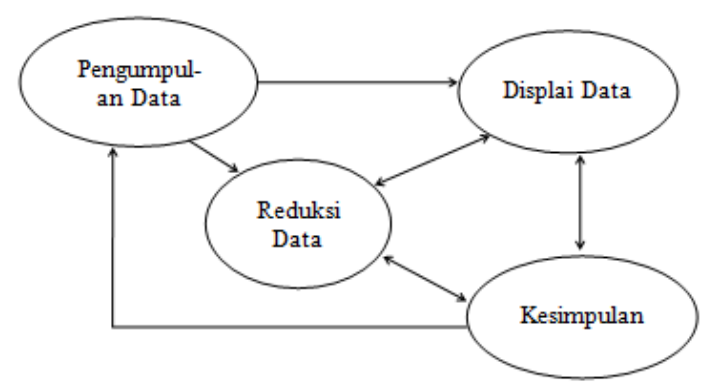

Figure 1. Interactive Analysis Model from Miles and Huberman

\section{3) Credibility Test Data}

Test the credibility of data or reliability to data qualitative research results, among others, done by increasing perseverance means to make observations in a more thorough and sustainable. Thus, the researcher did re-examination of existing data in the Office of Cooperatives, Micro, Small and Medium Enterprises Bandung and the Department of Trade and Industry Bandung, thus the 
certainty of data and sequence of events will be recorded with certainty and systematic. Re-examination of the data can be found wrong or true. In addition, researchers can also provide accurate and systematic description of the data.Furthermore, Triangulation is a test of credibility as checking data from various sources, various ways, and various times. Starting from the main source or in other terms to more recognize the problems that occurred, are as follows the Head Office of Cooperatives, Micro, Small and Medium Enterprises and Head of the Department of Trade and Industry and several Heads of Fields in both Departmentsdone by observation and interview both formal and informal in direct face to face in the Department of Cooperatives, Micro, Small and Medium Enterprises Bandung and the Department of Trade and Industry Bandung. Triangulation conducted on various sources provides a description of the different views of the subject of research.

\section{RESULTS AND DISCUSSION}

There were 28 questionnaires distributed by the researcher to respondents namely Head of Division and Head of the Second Section of the Department that consisted 28 statement items. After the questionnaires collected, the data is processed using Statistical Product and Service Solutions (SPSS) program.

Based on the results of Organizational Designvariables questionnaire stated into 12 items, namely the number one to 12 obtained results for the variable of Organization Design that showed the ten valid items, while two items are declared invalid and those are the item number 1 and item 3, it is not included in the next analysis, consequently the total score will change, while the results of work Performance variables questionnaire stated into the 16 items of 13 to 28 obtained results for work Performance variables that showed valid, there are 16 items, the total score does not change. New total scores for both variables can be seen in the table below:

\begin{tabular}{ccc}
\hline No Responden & $\begin{array}{c}\text { Total Skgr Baru } \\
\text { Variabel Bebas }\end{array}$ & $\begin{array}{c}\text { Total Skgr. } \\
\text { Variabel Terikat }\end{array}$ \\
\hline 1 & 38 & 68 \\
2 & 39 & 65 \\
3 & 40 & 65 \\
4 & 40 & 63 \\
5 & 37 & 60 \\
6 & 45 & 78 \\
7 & 45 & 78 \\
8 & 45 & 78 \\
9 & 38 & 57 \\
10 & 44 & 79 \\
11 & 23 & 61 \\
12 & 40 & 70 \\
13 & 29 & 57 \\
14 & 26 & 51 \\
15 & 34 & 54 \\
16 & 42 & 62 \\
17 & 40 & 64 \\
18 & 26 & 61 \\
19 & 28 & 44 \\
20 & 31 & 51 \\
21 & 28 & 56 \\
22 & 31 & 52 \\
23 & 41 & 73 \\
24 & 33 & 61 \\
25 & 26 & 69 \\
26 & 29 & 61 \\
27 & 30 & 59 \\
28 & 32 & 68 \\
Total & 980 & 1765 \\
\hline
\end{tabular}

Table 3. Operational Variable of Employee's Work Performance

Further description of reliability level of the questionnaire data can be seen in the following table:

\begin{tabular}{cccc}
\hline Variabel & $\begin{array}{c}\text { Nilai } \\
\text { Realibilitas }\end{array}$ & $\begin{array}{c}\text { Keriteria } \\
\text { Realibilitas }\end{array}$ & Keterangan \\
\hline $\begin{array}{l}\text { Desain } \\
\text { Organisasi }\end{array}$ & 0.730 & 0.6 & Realiabel \\
Kinerja & 0.880 & 0.6 & Realiabel \\
\hline
\end{tabular}

Table 4. Reliability Variable of Organization Design towards Work Performance

Relations in the form of correlation between Organizational Design with Work Performance of the discussion is done through Coefficient of Spearman Rank formula where as independent variables or variables that influenced by work performance is Organizational Design dependent variable or those influenced by work performance as well. Based on the Alpha Cronbach calculation above showed a whole reliable variable because the price that obtained is more than 0.6 . 
Further description of the regression questionnaire data can be seen as follows:

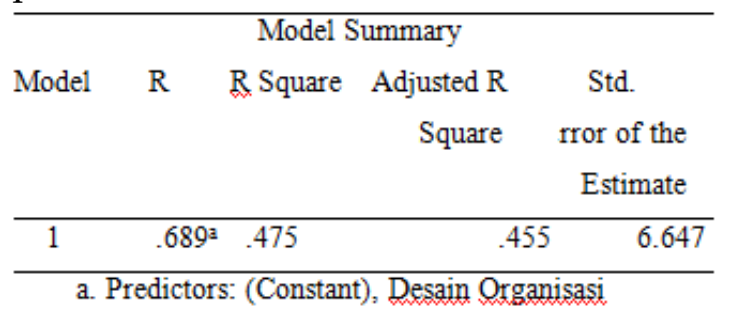

Table 5. Regression Coefficient Test

Based on criteria of determination influence of organization design toward work performance as much as 0.475 , it means that the percentage change on work performance can be explained by organization design through linier relations between organization design with Cooperative Department of employee work performance, micro, small and medium enterprises industry and trade as much as $47.5 \%$.

\begin{tabular}{|c|c|c|c|c|c|c|}
\hline \multicolumn{7}{|c|}{ Coefficients" } \\
\hline \multirow[t]{3}{*}{ Model } & & & \multicolumn{4}{|c|}{ Standardized } \\
\hline & & Unstandardzed & dCoefficients & Coefficients & & \\
\hline & & B & Std. Error & Beta & $t$ & Sig. \\
\hline 1 & (Constant) & 30.877 & 6.746 & & 4.577 & .000 \\
\hline & Desain Organisasi & .919 & .189 & .689 & 4.852 & .000 \\
\hline
\end{tabular}

Based on the regression equation, it shows that $\mathrm{Y}=30.877+0.919 \mathrm{X}, \mathrm{Y}=, \mathrm{Y}=$ Work Performance $X=$ Organizational Design, regression coefficient 0.919 on the design organization. This shows that the prediction of the organization's design affects the positive performance.

\begin{tabular}{|c|c|c|c|c|c|c|}
\hline \multirow[b]{2}{*}{ Model } & \multicolumn{6}{|c|}{ ANOYA } \\
\hline & & $\begin{array}{l}\text { Sum of } \\
\text { Saures }\end{array}$ & & & & \\
\hline \multirow[t]{3}{*}{1} & Regression & $\begin{array}{c}\text { Squares } \\
1040.117\end{array}$ & $\frac{\mathrm{Dt}}{1}$ & $\begin{array}{r}\text { Mean square } \\
1040.117\end{array}$ & $\frac{F}{23.539}$ & $\frac{000^{2}}{.0 .0}$ \\
\hline & Residual & 1148.847 & 26 & 44.186 & & \\
\hline & Total & 2188.964 & 27 & & & \\
\hline
\end{tabular}

The impact of organizational design on the work performance in the Department of Cooperative, Micro, Small and Medium Enterprises Bandung and Department of Trade and Industry Bandung amounted to 0.689 or $68.9 \%$ while other factors that was not measured in this study is 0.311 or
$31.1 \%$, the research findings are the quality of human resources andfacilities (a united office).

In this research, the FGD results measured the research variables based on the analytical tool of bothhuman resource institution variables, there is no authority nor limited authority, the government lacks of rationality in providing budget, a lot of institutions that should not have existed due to extending chain of command and also inappropriate budget allocation such as institutional region (the opinion of Head of Cooperative, Micro, Small and Medium Enterprises Bandung, Mr. Priana). The institutional effectiveness of the Cooperative is only six months hence it cannot be seen institutionally although the cooperative has been started since the first Indonesia's independence term around 70 years ago. The existed cooperatives are about 2565 while the active one is around 800 Cooperatives.

Those inactive cooperatives caused by a lot of factors such as the number of moneylenders who are acting on behalf of the mobile cooperative that does not reflect the Cooperative. For example, for $2 \%$ service the parties took the services up to $20 \%-30 \%$, hence there is Kredit Melati Program (Against Moneylender), so it needed the attention of the following departement concerning moneylenders such as:

1. Advancing Cooperatives (healthy and active)

2. Overseeing Cooperatives (in order to not to harm the society)

3. Take care of Non - Formal Enterprises (PKL)

The work performance of Cooperative Department in its work report performed IT (work performance is directly proportional to the activity) based on work performance or electronic remuneration of work performance. 
The emergence of new Institutions of Trade and Industry with new SOTK although the budget has not moved from two years ago, the work is more focused (Mr. Husen, Secretary of Trade and Industry Department of Bandung) when old SOTK oversees six fields and four Technical Implementation Units but when the new SOTK of Department of Trade and Industry Bandung oversees five fields and two Technical Implementation Units, the segregation are three areas of trade affairs and two fields of industrial affairs. More broadly for the training included the Foreign Trade, there is program "Little Bandung Wall" and "Little Bandung Store" as a promotion of Indonesian products, since 2015 with various types (wall, store, mobile for the exhibition, catalog and web) which is one of the activities that conducted in regional and abroad so far hasbeen running in Malaysia and South Korea. As in South Korea (Seoul and Busan), "Little Bandung Wall" is located at Bali Distro cafe that is one of the owner is Bandung Citizen, the promotion is conducted by using the space on the cafe's wall to store the products (utilizing the small spaces).

Inside the country, there is planned "Little Bandung Nusantara" (store), product's promotion by trading by the Department of Cooperatives. All Small and Medium Enterprises that are managed by Cooperatives are part of "Little Bandung", then surveyed by Regional and Foreign Trade Division of Bandung Trade and Industry Service whether they ready to go internationally or still need the training, if it is ready to be curated with expert curator in their field then it selected according to market intelligent (according to market segment target).

With the new SOTK, Department of Trade and Industry Bandung is more focused because there are some specific areas that move to other agencies including Creative Industry to the Department of Tourism Bandung, the authority of the Department of Trade and Industry Bandung is to open metrological, while the settlement of consumer disputes special agency moved to the Province. This new SOTK also has a positive impact on the role of supervision and price control, collaboration with the Department of Trade and Industry Bandung and Cooperatives it still needs to do cooperation, especially the pattern of micro, small and medium business development and center business in Bandung.

Law No. 23 The division of MicroMedium Enterprises concerning Micro Enterprises is a matter of City and then Small Business of Provincial Affairs, Medium Enterprises of the Central Business Unit is only the facilitation of SMEs, guidance, legitimate authorization in the recommendation center of Cooperatives, Micro, Small and Medium Enterprises regulations regulation 33 verse 1.

The Field of Valuation, Monitoring and Enforcement, with this field, recalls the Movement of Cooperatives on the principle of cooperative identity. The task is to conduct an assessment and health towards Cooperative, reminding the Cooperative that does not conduct annual member meetings, audit facilitation, in cooperation with public accounting firm, to cope with loan sharks in cooperation with NGOs and DompetDhuafa, then the field of Resources and Industrial Promotion, carrying out some affairs in the field of industrial scope of resources and promotion, promotional affairs and industry cooperation, facilitation of industrial resources including human resources development for industry, production, raw materials etc. 
General and Employees Sub Division, the segregation of both departments came from the authority and potential of the targeted object, such as to overcome the problem of moneylender, they made the division of cooperative supervision. The Non-Formal Business Sector focused on fostering street vendors. The problem of personnel is only divided into two (from one old SOTK service) while the design of organizational structure has been developed, facilities and infrastructure are still in one building. It needs to improve the spirit to improve the work performance at both departments. Only by dividing up employees without recruiting new employees, echelon IVa has no implementer yet. If done equitably in order all echelon IVa filled it will be impossible because of the task risks difference.

The structure became wider, the targeted object is wide but each structure is more focused, the supervisory area of the cooperative is more preventive and the priority scale curative to the TKD (Performance Allowance Area) the spirit improves the performance but if on the execution that exceeds the limit generated with the organizational structure of authority and the sequence of tasks is adjusted to activities with the implementation of employee work performance.

With the segregation of two divisions of this Department, there are things that needed to be in the attention those are, personnel that divided into 2 , the swelling organization structures, the infrastructure in one building and mobility that added has not ready yet operationally.

Talking about Bandung it cannot be separated from regional autonomy where Bandung has the right to manage its own regional affairs; there is a tendency of centralization to the center for crucial matters. Looking at the intermediate affairs into the central business but at the execution, inthe structure still exists within the region;this kind of structural policies need to be evaluated on the authority of the policy that only own by the central governance.

Data analysis by conducting the study of data collection results, the results of data displays will reduce the data by performing analysis the measuring tools of both variables as follows:

1) Work Specialization

Based on the results of interviews and FGDs with Heads of Cooperatives, Micro, Small and Medium Enterprises he said that:

"The government is lack of rationality in providing the budget, especially in Bandung city the specialization of work is too long on hierarchy, particularly in Bandung sub-region government should not have existed!"

The authors analysis that due to the chain of command is too long, the Head of Department of Cooperative, Micro, Small and Medium Enterprises said that the regional institution does not need to exist. According to the authors, it still have to exist but for certain affairs related to the cooperative sectors its study should be more optimized. It still acceptable because the authority is very limited and the allocation of funds is not appropriated also the institutional effectiveness of the Cooperative has just been 6 months so it has not shown its effectiveness.

If we link it with the quality of work, the regional apparatuses do have to understand the ins and outs of cooperatives and then trade permit for new entrepreneurs and others, then seeing from the side of quantity of work that is the amount of work construction scope that quiet large, it needs the 
coordination among sub-regional governments in onedistrict.

Based on the results of interviews with the personnel in the Department of Commerce and Industry Bandung said that:

"The employees of the Department of Trade and Industry Bandung, although the working periods have not been a good self - confidence thus many works always distributed to head such as in the same level of Head Division!"

If seen from the job knowledge or the average of worker knowledge in the Department of Trade and Industry Bandung, it seems that they have not understood the basic tasks that should be the function, creativity is also need to be built because all this time they only carry out routine work tasks, as well as the initiative must continue the optimize approach so the employees not only carry out the routine tasks but they have the power of thinking, innovation, and creativity for the Department of Trade and Industry Bandung, because when talking about trade regarding the issue of ideas that make one job, trade related to creativity and the creative power to market its products thus it needs a creative employee, not just a routine task.

2) Chain of Command

Based on the results of interviews with the Secretary of the Department of Trade and Industry Bandung obtained the following data:

"The emergence of the new institution of Trade and Industry Department in Bandung that brings 5 fields, 3 fields of trade affairs and 2 industry affairs cause the works more focused!"

The author analyzes that the chain of command now has became two because there are two commandments that means two Head of Departments sothe instructions given are more focused on the basic tasks of their respective duties; this implies to us that the chain of command is clearer and more directed from the new SOTK structure.

If linked to thecooperation,the coorperation of both partiescan be reflected when the promotion activities of trade and industry and micro, small and medium enterprises in "Little Bandung" at a country.

3) Authority

Based on the results of interviews submitted by the two Departments that:

"Authority is now concentrated in the respected Department. This has resulted in the two departments that having different authorities!"

The author's analysis of the authority of the two Departments related to the basic tasks of different functions requires coordination between fields when talking about a job that is almost the same as promoting creative industry or trade promotion with supervision and health control Cooperative, Cooperative financing development, promotion Cooperative, formal business field which is in this case requires authority that can produce one same job in order to improve the effort of improving the economy in Bandung which mainly related to the purchasing power of the society.

4) Management Range

Based on interviews with the Head of Department of Cooperative, Micro, Small and Medium Enterprises and Department of Trade and Industry in Bandung, that:

"The range of management has been done in accordance with the function of duties, even due to Department has just implemented 
the new SOTK so it has not been considered as optimized!"

If it viewed that compared with the number ofemployees, these are justpart of the employees that divided in two amounts so the number of employees seema little while there are so many fields.

5) Departments

If vied from the structure that at first had 6 united Department fields, now after the Departments separated, there is a department with 4 and 5 fields that makes the structure becomes fat.

The results of interviews with Head of Sub Division Personnel Department of Cooperatives, Micro, Small and Medium Business Bandung that:

"The structure even becomes swollen from six to nine fields when it has been separated while the number of employees divided in to 2 and there is no recruitment"

If it is analyzed based on job knowledge, then it appears that the job knowledge of the employees should be more improved either with training or education related to the duties and responsibilities of their work.

6) Formalization

There are three types of formalization: work-based formalization, formalization based on work flow, and regulatory formalization. This has not optimized yet, especially if itis associated with personal quality, based on interview with Sub Division of Personnel "the three formalizations are still needed to be increased in both departments"

This is possibly occurred so that the new Department implemented new SOTK up to the stage of implementation and continues to do fixation in terms of structure and implementation of the work.

Related to the e-commerce, researchers conducting interviews with head of e-Commerce Development Section resulted the needs of creativity and this innovation requires cooperation in handling this case regardless of the cooperation among stakeholders in this e-commerce, these are the interview's result with the head of ecommerce division:

a) In Bandung City many micro, small and medium enterpreneurs already used e- commerce for marketing, so when the developing this departement, formed the section of e-commerce development.

b) Since 2015 and 2016 have been working with Facebook and some other business actors have been facilitated to be promoted through Facebook, it planned that they will work with other institutions such as Tokopedia.

c) Currently section of e-commerce development is still conducting basic training to the SMEs to recognize e-commerce by inviting them especially those who do not know e-commerce.

If it is associated with the spirit of cooperation, it needed cooperation that coexist along with the job that need internet devices and special skills.

The analyses of the research findings are the authority of medium enterprises is in the center governance, the authority of small enterprises is in the province and the 
authority of micro enterprises is in the city. FGD results turned out to be in the structure and all in the authority of the creative industrial city, its authority in the Tourism Department, whereas in the RPJMD is obviously the industrial authority overlapping to workand shouldbe put together among stakeholders from the Center, Provincial and City / District.

With the new SOTK actually the work is more focused but only constrained by two employees segregation, the organizational structure is swollen, when in the old SOTK there are six areas, when separated from the Department of Cooperatives, Micro, Small and Medium Enterprises in four areas, Trade and Industry Departments in five areas (three affairs trade, two industrial affairs) this is a fat job fat structure, then the infrastructure is still merge, the old building is still in use for two departments, plus the mobility is not ready.

\section{CONCLUSION}

From this research it can be concluded that with this new SOTK both departments become more focused on the work although there are some affairs that are taken over by the center governance such as medium-sized enterprises by the center, small business by province, and micro business by city but in reality, in the organizational structure of small and medium enterprises still exist in the structure of the City Servicethat handled by the city. This showed that there is still overlapping of work specialization and authority that has not been optimized from center to region makes it difficult in the work process, either on both the guidance or the pattern of accompaniment.

The results of quantitative data analysis indicate that the validity of measurement in the two variables of Organization Design and Work Performance as well as the high reliability means measuring tool or tool of analysis of the two variables are very suitable for use in measuring the case that being faced in this research which became the scope of research.

The analysis of qualitative data based on the observation and interviews from the number of employees were not adequate when compared with the volume of work, for examples there are employee in one area who are not more than five people while the number of SMEs to be fostered and accompanied more than 5000 and more than 200 with different types of business, this requires recruitment of employees who are certainly in accordance with educational background and employee skills that neededto handle both departments in accordance with the arable field.

Suggested to the Department of Trade and Industry Bandung City regarding creative industries should not be given to the Department of Culture and Tourism of Bandung, with the Department of Culture and Tourism of Bandung is enough to applied cross-functional coordination, it does not need authority thus the Office of Culture and Tourism Bandung for the creative industry, this related to the guidance and work field in the Department of Trade and Industry Bandung. Tourism affairs is just a program of tourism marketing development and tourism destination development programs related to the Trade and Industry Office of Bandung City, one of its tasks is the creative development and 
techno economic (RPJMD 2013 - 2018). Theoretically, this research is expected to produce new concepts or findings of research that will certainly enrich organizational theory and studies related to organizational structure and public institutions related to performance.

This study resulted in the organizational structure model of the two departments that adjusted to the FGD information research wich was the enrichment of the existing structure that and not changing the total and it only enriched it. Furthermore, this study also created a collaboration model between the two agencies related to the task of the promotional function simultaneously.

\section{DAFTAR PUSTAKA}

Robbins, Stephen P. 1994. Teori Organisasi Struktur, Desain dan Aplikasi.Arcan. Jakarta.

Ivancevich, John M, Konopaske Robert \& Matteson Michael T 2007, Perilaku Dan Manajemen Organisasi(Alih Bahasa Gina Gania), Edisi Tujuh, Erlangga. Jakarta.

Griffin. 2004. Manajemen. Edisi Ketujuh, Erlangga. Jakarta.

UR.Wisnu, Dicky, Nurhasanah, Siti, 2005.Teori Organisasi Struktur dan Desain.Edisi kedua, Universitas Muhammadiyah .Malang Press. Malang.

Daft, Richard L, 2010. Era BaruManajemen. Edisi 9, Buku 2.SalembaEmpat. Jakarta.

Robbins,Stephen P. 2003. Perilaku Organisas.Index. Jakarta.

Gomes Cardoso, Faustino. 2003.Manajemen Sumber Daya Manusia. Andi Yogyakarta.Yogyakarta.

Mattew B. Miles dan Michael Huberman.(1992). Analisis Data Kualitatif.UI-Press. Jakarta.
Ahmad Hanfan. (2017). Membangun

Keunggulan Produk Ikonik Untuk

Meningkatkan Kinerja Pemasaran UMKM [Establishing Advantages of Iconic Products to Improve Marketing Performance of SMEs]. DeReMa Jurnal Manajemen. 12(2), 162-186.Universitas Pelita Harapan. Jakarta.

Hadi Ismanto dan Tohir Diman. (2014).

Analisis Efektivitas Pemberian

Pinjaman Program Pembiayaan Umkm Oleh Koperasi. Jurnal Economia.10(2), 148-164. UNY. Yogyakarta.

Amir Syarifudin Kiwang, dkk. (2015).

Analisis Kebijakan dan Efektivitas

Organisasi.Jurnal Kebijakan dan

Administrasi Publik (JKAP).19(1),

71-80. UGM. Yogyakarta.

Widya Exsa Marita. (2015).Pengaruh

Struktur Organisasi dan Ukuran

Perusahaan Terhadap Penerapan

Business Entity Concept.AKRUAL:

Jurnal Akuntansi. 7(1), 18-40.

UNESA. Surabaya.

Setiadi Umar. (2008). Implementasi

Knowledge Management pada

UMKM Indonesia Untuk

Meningkatkan Daya Saing UMKM dalam Dunia Internasional. Jurnal

Siasat Bisnis. 12(2), 149-160. (PPM)-

FE UII. Jakarta.

Tjutju Fatimah. (2011). Strategi

Pemberdayaan Usaha Mikro, Kecil dan Menengah (Umkm) Dalam Menghadapi Globalisasi.Jurnal Ilmiah Econosains. 9(1), 49-61.UNJ. Jakarta.

Felix A. Sutanto, dkk. (2015). Penerapan

E-Commerce Berbasis CMS dan SEO Untuk Toko On-Line UMKM.Jurnal Abdimas. 19(2),91-100.LP2MUNS. Semarang.

Barjesteh, H., \& Moghadam, B. A. (2014). Teacher questions and questioning 
strategies revised: a case study in

EFL classroom in Iran. Indian

Journal of Fundamental and Applied

Life Sciences, 4(2), 651-659.

Campbell, J., \& Mayer, R. E. (2009).

Questioning as an instructional

method: does it affect learning from

lectures? Applied Cognitive

Psychology, 23, 747-759.

Diyyab, E. A., Abdel-Haq, E. M., \& Aly, M.

A. (2014). Using a multimedia-based program for developing student teachers' EFL speaking fluency skills. Journal of Faculty of Education Benha University, 25(99), 5-6.

Efrizal, D. (2012). Improving students' speaking through communicative language teaching method at Mts Jaalhaq, Sentot Ali Basa Islamic boarding school of Bengkulu, Indonesia . International Journal of Humanities and Social Science, 127134.

Fakir, S. A. (2014). Testing of oral English language in the intensive English program at the college of languages (university of Aden). International Journal of English and Education, 183.

Febriyanti, E. R. (2011). Teaching speaking of English as a foreign language: problems and solutions. Jurnal Bahasa dan Sastra, 1(2), 1-16.

Feng, Z. (2013). Using teacher questions to enhance EFL students' critical thinking ability. Journal of Curriculum and Teaching, 2(2), 147-153.

Harmer, J. (2000). How to teach English . Beijing: Foreign Language Teaching and Research Press.

Iswara, A. A., Azib, A., \& Rochsantiningsih, D. (2012). Improving students' speaking fluency through the implementation of trivia-based activity in university students. Jurnal Pendidikan Bahasa Inggris, 1(1), 1-17.

Mohammadipour, M., \& Rashid, S. M. D. (2015). The impact of task-based instruction program on fostering ESL learners' speaking ability: a cognitive approach. Advances in Language and Literary Studies, 6(2), 113-126.

Nazara, S. (2011). Student's perception on EFL speaking skill development . Journal of English Teaching, 28-43.

Oradee, T. (2012). Developing speaking skills using three communicative activities (discussion, problemsolving, and role-playing). International Journal of Social Science and Humanity, 2(6), 533535.

Al-Zahrani, M. Y., \& Al-Bargi, A. (2017). The impact of teacher questioning on creating interaction in EFL: a discourse analysis. English Language Teaching, 10(6), 135-150.

Barjesteh, H., \& Moghadam, B. A. (2014). Teacher questions and questioning strategies revised: a case study in EFL classroom in Iran. Indian Journal of Fundamental and Applied Life Sciences, 4(2), 651-659. Campbell, J., \& Mayer, R. E. (2009). Questioning as an instructional method: does it affect learning from lectures? Applied Cognitive Psychology, 23, 747-759.

Diyyab, E. A., Abdel-Haq, E. M., \& Aly, M. A. (2014). Using a multimediabased program for developing student teachers' EFL speaking fluency skills. Journal of Faculty of Education - Benha University, 25(99), 5-6.

Efrizal, D. (2012). Improving students' speaking through communicative language teaching method at Mts 
Ja-alhaq, Sentot Ali Basa Islamic boarding school of Bengkulu, Indonesia . International Journal of Humanities and Social Science, 127-134.

Fakir, S. A. (2014). Testing of oral English language in the intensive English program at the college of languages (university of Aden). International Journal of English and Education, 183.

Febriyanti, E. R. (2011). Teaching speaking of English as a foreign language: problems and solutions. Jurnal Bahasa dan Sastra, 1(2), 1-16.

Feng, Z. (2013). Using teacher questions to enhance EFL students' critical thinking ability. Journal of Curriculum and Teaching, 2(2), 147-153.

Harmer, J. (2000). How to teach English . Beijing: Foreign Language Teaching and Research Press.

Iswara, A. A., Azib, A., \& Rochsantiningsih, D. (2012). Improving students' speaking fluency through the implementation of trivia-based activity in university students. Jurnal Pendidikan Bahasa Inggris, 1(1), 1-17.

Mohammadipour, M., \& Rashid, S. M. D. (2015). The impact of task-based instruction program on fostering ESL learners' speaking ability: a cognitive approach. Advances in Language and Literary Studies, 6(2), 113-126.

Nazara, S. (2011). Student's perception on EFL speaking skill development . Journal of English Teaching, 28-43.

Oradee, T. (2012). Developing speaking skills using three communicative activities (discussion, problemsolving, and role-playing). International Journal of Social
Science and Humanity, 2(6), 533535.

Pishkar, K., Moinzadeh, A., \& Dabaghi, A. (2017). Modern English drama and the students' fluency and accuracy of speaking. English Language Teaching, 10(8), 69-77.

Rahmawati, Y., \& Ertin. (2014). Developing assessment for speaking. Indonesian Journal of English Education, 1(2), 202.

Strack, R. W., Magill, C., \& McDonagh, K. (2004). Engaging youth through photovoice. Health Promotion Practice, 5(1), 49-58.

Thornbury, S. (2005). How to Teach Speaking. London: Pearson Education Limited.

Tuan, N. H., \& Mai, T. N. (2015). Factors affecting student's speaking performance at La Thanh Hien high school. Asian Journal of Educational Research, 3(2), 8-23.

Ur, P. (1996). A course in language teaching. Cambridge: Cambridge University Press.

Vebriyanto, D. A. (2016). Teacher's questions in EFL classroom interaction. Journal Vision, 4(2), 279-303.

Wahyudi, D. (2017). The use of questioning technique to enhance students' speaking ability. Indonesian Journal of Integrated English Language Teaching, 3(1), 115.

Wang, C., \& Burris, M. A. (1997). Photovoice: concept, methodology, and use for participatory needs assessment. Health education \& behavior, 24(3), 369-387.

Wangru, C. (2016). The research on strategies of college English teachers classroom questioning. International Education Studies, 9(8), 144-158. 
Yang, Y. I. (2014). The implementation of speaking fluency in communicative language teaching: An observation of adopting the $4 / 3 / 2$ activity in high schools in China. International Journal of English Language Education, 2(1), 193-214. 